\title{
KOMPARASI KINERJA PERBANKANSYARIAH INDONESIADAN MALAYSIA DENGAN PENDEKATAN MAQASHID SYARI'AH INDEX (MSI) (Studi Pada Perbankan Syariah Indonesia dan Malaysia Tahun 2011-2015)
}

\author{
Amalia Tery Luana Devi \\ Fitriyah \\ Jurusan Manajemen Fakultas Ekonomi UIN Maulana Malik Ibrahim Malang \\ Email: amaliatery@gmail.com \\ fitriyah_feuin@yahoo.com
}

\begin{abstract}
Measuring the performance of sharia banking by using conventional measurement has not been able to show the assessment of Islamic banking performance in accordance with the purpose of sharia. There are differences in sharia banking with conventional banking, so it needs performance measurement from other side that is devoted to sharia banking. This research aimed at analyzing and comparing the performance of Islamic banking in Indonesia and Malaysia by using Maqashid Syariah Index (MSI) approach. This research object of 11 Sharia Commercial Banks in Indonesia and 15 Sharia Commercial Banks in Malaysia that have been operating during 2011-2015. Sources of research data used annual reports of each bank. The steps to measure bank performance with Maqashid Syariah Index (MSI) is ratio performance assessment, assessment of performance indicators and last assessment of the Maqashid Syariah Index (MSI). The results showed that there were differences in performance based on the value of Maqasid Syariah Index (MSI) between Indonesian and Malaysian sharia banks in 2011-2015. Sharia banking performance in Indonesia was better in achieving maqashid sharia than sharia banking in Malaysia. The highest rating of Islamic banking in Indonesia was Panin Syariah Bank (BPS) and Islamic banking in Malaysia was HSBC Amanah Malaysia Berhad (HSBC)
\end{abstract}

Keywords: Banking Performance, Syariah Banking, Maqashid Syariah Index (MSI)

Perbankan sebagai salah satu lembaga keuangan mempunyai peran strategis dalam menyelaraskan, menyerasikan serta menyeimbangkan berbagai unsur pembangunan. Kehadiran perbankan syari'ah telah menjadi udara segar bagi dunia perbankan dan nafas bagi perekonomian saat ini. Hadirnya perbankan syari'ah diharapkan dapat lebih memaksimalkan penerapan nilai-nilai syari'ah dalam semua aspek operasionalnya. Perbankan syari'ah juga diharapkan mampu memberikan layanan yang lebih baik dalam hal kinerja keuangan dan non keuangannya dibandingkan dengan perbankan konvensional.

Menurut data statistik Ernst \& Young (2016), partisipasi perbankan syariah secara internasional terus menunjukkan pertumbuhan aset di lima tahun terakhir, yaitu pada tahun 2010 - 2014 tumbuh sebesar $16 \%$. Hal tersebut didukung data statistik IFSB (Islamic Financial Services Board, 2015) yang menyebutkan bahwa secara keseluruhan, aset perbankan syariah global diperkirakan berjumlah sekitar USD 1.56 triliun pada akhir 2014.
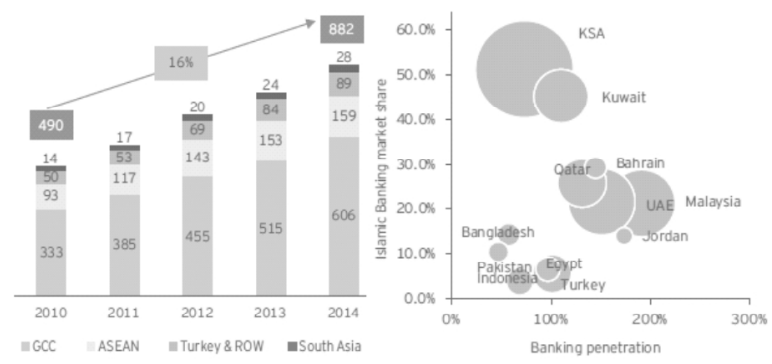

Sumber : Ernst \& Young, 2016

Gambar 1 Grafik Pertumbuhan Aset dan Market Share Perbankan Syari'ah

Perkembangan Perbankan Syari'ah yang terus mengalami peningkatan harusnya diimbangi dengan kinerja bank syari'ah dalam mewujudkan kepercayaan Stakeholder atas dana yang diinvestasikan. Untuk mewujudkan kepercayaan tersebut maka dibutuhkan alat pengukuran kinerja pada perbankan syariah tersebut. Namun, pengukuran kinerja suatu 
perusahaan di dunia global, termasuk perbankan syariah masih banyak yang menggunakan pengukuran rasio-rasio keuangan seperti, CAMELS (Capital, Asset, Management, Earning, Liquidity, Sensitivity of Market Risk), RGEC (Risk Profile, Good Corporate Governance, Earnings, Capital), EVA (Economic value Added) dan Profitabilitas.

Apabila perbankan syariah hanya menggunakan pengukuran yang sama dengan perbankan konvensional untuk mengukur kinerjanya, akan terdapat nilai yang tidak sebanding dari penggunaan indikator kinerja perbankan konvensional dengan objek yang lebih luas yang terdapat pada perbankan syariah (Mohammed et al, 2008).

Padahal, bank syariah merupakan salah satu lembaga keuangan syariah yang kegiatan usahanya sejalan dengan prinsip-prinsip dasar dalam ekonomi Islam. Tujuan ekonomi Islam bagi bank syariah tidak hanya berfokus pada tujuan komersil (profit oriented), tetapi juga mempertimbangkan perananya dalam memberikan kesejahteraan secara luas bagi masyarakat (maslahah). Kontribusi bank syariah untuk turut ikut serta dalam memberikan kesejahteraan masyarakat merupakan salah satu bentuk peranan bank syariah dalam melaksanakan fungsi sosialnya. Hal ini sangat berbeda dengan sistem keuangan konvensional yang memusatkan pada aspek transaksi dan ekonomi saja. Karakter yang dimiliki bank syariah memungkinkan pengukuran kienerja dari sisi lain yang khusus bagi bank syariah. Sehingga dapat diketahui kesesuaian kinerja perbankan syariah dengan tujuan syariah pada umumnya (maqashid syariah).

Dalam hal ini penilaian kinerja bank syariah dapat diukur menggunakan konsep maqashid syariah. Konsep tersebut merupakan salah satu upaya dalam mengimplementasikan pengukuran kinerja yang khas dan sesuai dengan maqashid syariah bagi perbankan syariah.Lebih lanjut, konsep maqashid syariah ini dikembangkan dari teori Abu Zahrah bahwa ada tiga tujuan konsep maqasid syariah secara lebih luas dan umum yaitu :Tahdzib al-fard (pendidikan individu), Iqamah al-adl (menegakan keadilan), dan Jalb almaslahah (kebaikan).

Pengembangan indeks maqasid syariah sebagai penilaian kinerja bank syariah telah dilakukan pengujian secara empiris oleh Mohammed et al., (2008) "The Performance Measures of Islamic Banking Based on the Maqasid Framework"yang menghasilkan sebuah pengukuran kinerja keuangan yang disebut Maqasid Index (MI),Dalam penelitian
Roza (2015) mencoba mengukur kinerja kinerja perbankan syariah melalui aspek maqashid shariah dan hasil penelitiannya menunjukkan bahwa hasil pengukuran kinerja yang sesuai dengan operasional bank syariah adalah dengan Indeks Maqasid Syariah.

Atas dasar latar belakang tersebut penelitian ini memiliki fokus untuk melakukan pengukuran kinerja perbankan syariah dengan menggunakan Maqashid Syariah Index (MSI), kemudian melakukan perbandingan nilai indeks maqashid syariah dan tiga nilai tujuan syariah pada perbankan syariah di Indonesia dan Malaysia. Perbandingan diantara kedua negara tersebut dirasa cukup penting mengingat kedua negara tersebut merupakan Negara serumpun dengan penduduk mayoritas muslim di Asia Tenggara dan memiliki peringkat yang tinggi dalam perkembangan perbankan syariah dunia.

\section{MAQASID SYARIAH}

Secara etimologi maqashid al-syari'ah terdiri dari dua kata, yakni maqashid dan syariah. Maqashid adalah bentuk jamak dari maqshud yang berarti kesengajaan, atau tujuan. Adapun syari'ah artinya jalan menuju air, atau bisa dikatakan dengan jalan menuju ke arah sumber kehidupan. Dengan demikian, maqashid al-syari'ah dapat diartikan sebagai tujuan Allah sebagai shari' dalam menetapkan hukum yang terintegrasi terhadap hambanya. Inti dari maqashid alsyari'ah adalah untuk mewujudkan kebaikan sekaligus menghindarkan keburukan atau menarik manfaat (maslahah). (Fauziyah \& Riyadi, 2014)

Maqashid Syariah Index (MSI) merupakan metode pengukuran kinerja perbankan syariah yang dirumuskan oleh Mustafa Omar Mohammed, Dzuljastri Abdul Razak dan Fauziah Md Taib (2008) dalam penelitiannya yang berjudul "The Performance Measures of Islamic Banking Based on the Maqasid Framework". Mohammed et al, menggunakan 3 variabel atau tujuan dalam pengukuran kinerja perbankan syariah yang diadopsi dari teori maqashid syariah oleh Abu Zahrah. Ketiga tujuan tersebut diantaranya tahdzib al-fard (mendidik individu), iqamah al-adl (menegakkan keadilan), dan maslahah (kesejahteraan).

Tujuan pertama yaitu pendidikan individu menyatakan bahwa kinerja perbankan dinilai dari bagaimana perbankan syariah mampu merancang program 
pendidikan dan pelatihan baik bagi karyawan dengan nilai-nilai moral, sehingga terdapat peningkatan pada kemampuan dan keahlian para karyawan. Tujuan yang kedua yaitu keadilan, penilaian kinerja yang kedua ini didasarkan pada tujuan perbankan syariah untuk dapat memastikan kejujuran dan keadilan dalam semua transaksi dan kegiatan usaha yang tercakup dalam produk, serta memastikan bahwa seluruh

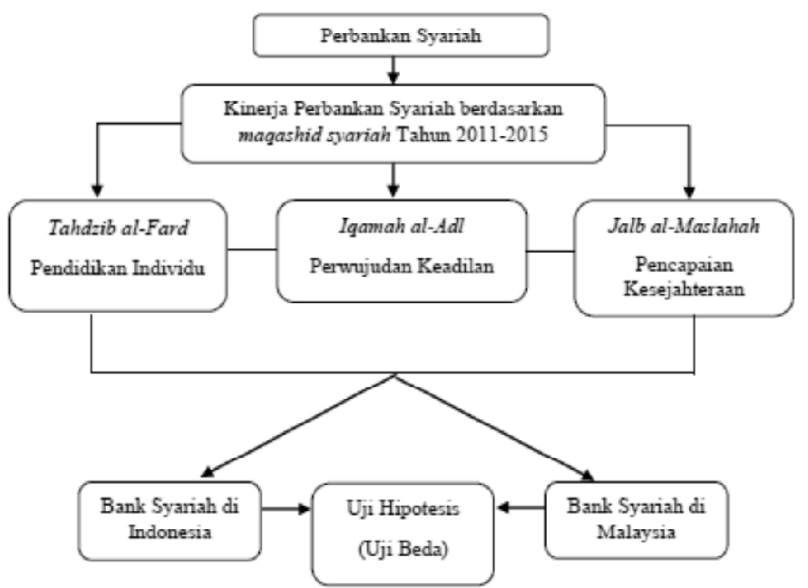

aktivitas perbankan syariah merupakan free interest. Tujuan ketiga yaitu pencapaian kesejahteraan yaitu perbankan syariah harus mengembangkan proyekproyek investasi dan pelayanan sosial untuk meningkatkan kesejahteraan masyarakat (Imansari, 2015).

Berdasarkan landasan teori yang dijabarkan diatas, peneliti mencoba merumuskan kerangka dari penelitian yang menggambarkan perbandingan ratarata kinerja perbankan syariah di Indonesia dan rata-rata kinerja perbankan syariah di Malaysia berdasarkan teori mqashid syariah yang diadopsi dari Abu Zahrah

Mengacu pada model tersebut, maka rumusan hipotesis yang dibangun adalah sebagai berikut :

H0 :Tidak terdapat perbedaan kinerja berdasarkan nilai Maqasid Syariah Index (MSI) antara perbankan syariah Indonesia danMalaysia tahun 2011-2015

H1 :Terdapat perbedaan kinerja berdasarkan nilai Maqasid Syariah Index (MSI) antara perbankan syariah Indonesia dan Malaysia tahun 2011-2015

\section{Gambar 2 Kerangka Konseptual}

Tabel 1 Model Pengukuran Kinerja Maqashid Syariah

\begin{tabular}{|c|c|c|c|}
\hline Konsep & Dimensi & Elemen & Rasio Kinerja \\
\hline \multirow[t]{4}{*}{$\begin{array}{l}\text { Mendidik } \\
\text { Individu }\end{array}$} & \multirow[t]{2}{*}{$\begin{array}{l}\text { D1 (meningkatkan } \\
\text { pengetahuan) }\end{array}$} & E1 (hibah pendidikan) & $\begin{array}{l}\text { R1 (hibah pendidikan/total } \\
\text { biaya) }\end{array}$ \\
\hline & & E2 (penelitian) & R2 (biaya penelitian/ total biaya) \\
\hline & $\begin{array}{l}\text { D2 (menambah dan } \\
\text { meningkatkan kemampuan } \\
\text { baru) }\end{array}$ & E3 (pelatihan) & R3 (biaya pelatihan/total biaya) \\
\hline & $\begin{array}{l}\text { D3 (menciptakan kesadaran } \\
\text { masyarakat akan adanya } \\
\text { perbankan syariah) }\end{array}$ & E4 (publisitas) & R4 (biaya publisitas/total biaya) \\
\hline \multirow{3}{*}{$\begin{array}{l}\text { Mewujudkan } \\
\text { Keadilan }\end{array}$} & D4 (kontrak yang adil) & E5 (pengembalian yang adil) & R5 (laba/total biaya) \\
\hline & $\begin{array}{l}\text { D5 (produk dan layanan } \\
\text { terjangkau) }\end{array}$ & E6 (biaya yang terjangkau) & $\begin{array}{l}\text { R6 (piutang tak tertagih/total } \\
\text { investasi) }\end{array}$ \\
\hline & $\begin{array}{l}\text { D6 (penghapusan } \\
\text { ketidakadilan) }\end{array}$ & E7 (produk bank non bunga) & $\begin{array}{l}\text { R7 (pendapatan non bunga/total } \\
\text { pendapatan) }\end{array}$ \\
\hline \multirow{3}{*}{$\begin{array}{l}\text { Kepentingan } \\
\text { Masyarakat }\end{array}$} & D7 (profitabilitas) & E8 (rasio laba) & R8 (laba bersih/total aktiva) \\
\hline & $\begin{array}{l}\text { D8 (pendistribusian } \\
\text { kekayaan \& laba) }\end{array}$ & E9 (pendapatan operasional) & R9 (zakat/laba bersih) \\
\hline & $\begin{array}{l}\text { D9 (investasi pada sektor } \\
\text { riil yang vital) }\end{array}$ & $\begin{array}{l}\text { E10 (rasio investasi pada } \\
\text { sektor riil) }\end{array}$ & $\begin{array}{l}\text { R10 (penyaluran untuk investasi/ } \\
\text { total penyaluran) }\end{array}$ \\
\hline
\end{tabular}




\section{METODE PENELITIAN}

Penelitian ini merupakan penelitian kuantitatif dengan pendekatan studi deskriptif. Populasi yang digunakan adalah bank syariah yang berada di Indonesia dengan jumlah sebesar 12 dan bank syariah yang berada di Malaysia dengan jumlah sebesar 16 . Teknik pengambilan sampel dalam penelitian ini dilakukan secara purposive sampling, adapun kriteria dalam pengambilan sampel tersebut diantaranya:

a. Bank Umum Syariah yang berada di masingmasing Negara b. Bank Umum Syariah yang beroperasi dari tahun 2011-2015

c. Bank Umum Syariah yang mempublikasikan laporan tahunannya secara berturut-turut dari tahun 2011-2015

Dari pertimbangan-pertimbangan tersebut yang menjadi objek penelitian adalah 11 Bank Umum Syariah di Indonesia dan 15 Bank Umum Syariah di Malaysia.

\section{Pengukuran Maqashid Syariah Index (MSI)}

Metode pengukuran kinerja perbankan syariah yang digunakan dalam penelitian ini adalah metode

Tabel 2 Bobot Rata-rata Tujuan dan Elemen Pengukuran Maqasid Syariah

\begin{tabular}{lllc}
\hline Tujuan & Rata-rata Pembobotan & Unsur-Unsur & Rata-rata Pembobotan \\
\hline 1. Pendidikan & \multirow{2}{*}{30} & E1. Hibah Pendidikan/donasi & 24 \\
& & E2. Penelitian & 27 \\
& & E3. Pelatihan & 26 \\
& & E4. Publisitas & 23 \\
& & Total & $\mathbf{1 0 0}$ \\
\hline 2. Keadilan & 41 & E5. Pengembalian yang Adil & 30 \\
& & E6. Harga Produk Terjangkau & 32 \\
& & E7. Produk Non Bunga & 38 \\
& & Total & $\mathbf{1 0 0}$ \\
\hline 3. Kesejahteraan & 29 & E8. Rasio Laba Bersih & 33 \\
& & E9. Transfer Pendapatan & 30 \\
Total & $\mathbf{1 0 0}$ & E10. Rasio Investasi ke Sektor Riil & 37 \\
\hline
\end{tabular}

Sumber : Mohammed et al, 2008

yang digunakan oleh Mohammed et al, (2008) dalam bentuk Maqasid Syariah Index (MSI) yang diadopsi dari Abu Zahrah dalam konsep maqasid syariah. Ketiga tujuan diatas oleh Mohammed et al, (2008) diturunkan menjadi beberapa indikator pengukuran dengan menggunakan metode operasionalisasi Sekaran (2006). Hal ini agar ketiga tujuan syariah diatas dapat secara operasional diukur dan ditentukan nilainya. Sebagaimana ditunjukkan oleh Tabel 1.

Untuk mendapatkan hasil yang terbaik dari pengukuran diatas, maka dilakukan verifikasi dari model dan pembobotan pada setiap konsep dan elemen, sebagaimana terdapat pada Tabel 2 berikut ini :

Dalam penelitan Afrinaldi (2013) mengungkapkan bahwa terdapat tiga tahap yang akan dilakukan untuk mengukur kinerja maqasid syariah bank syariah, yaitu :
1. Menilai setiap rasio kinerja maqasid syariah yang terdiri dari 10 rasio kinerja yaitu :

a. Education Grant/Total Income (R11)

b. Research Expense/Total Expense (R21)

c. Training Expense/Total Expense (R31)

d. Publicity Expense/Total Expense (R41)

e. Profit Equalization Reserves (PER) / Net Or Investment Income (R12)

f. Mudharabah And Musyarakah Modes/ Total Investment Mode (R22)

g. Interest Free Income/Total Income (R32)

h. Net Income/Total Asset (R13)

i. Zakah Paid/Net Asset (R23)

j. Investment In Real Econoic Sectors/Total Investment (R33)

2. Proses menentukan peringkat dari setiap bank syariah dilakukan melalui Indikator Kinerja (IK) setiap bank syariah. Proses tersebut mengguna- 
kan Simple Additive Weighting Method (SAW) dengan cara pembobotan, agregat dan proses menentukan peringkat (weighting, aggregating and ranking processes). Secara sistematis, proses menentukan indikator kinerja dan tingkat sharia maqasid index tersebut dapat dijelaskan sebagai berikut:

a. $\quad$ Tahdzib al-fard $($ Mendidik Individu $)=$ Tujuan $1\left(\mathrm{~T}_{1}\right)$

Indikator Kinerja (IK) untuk Tujuan 1 sebagai berikut:

$$
\begin{aligned}
\mathrm{IK}\left(\mathrm{T}_{1}\right)= & \mathrm{W}_{11} \times \mathrm{E}_{11} \times \mathrm{R}_{11}+\mathrm{W}_{11} \times \mathrm{E}_{21} \mathrm{x} \\
& \mathrm{R}_{21}+\mathrm{W}_{11} \times \mathrm{E}_{31} \times \mathrm{R}_{31}+\mathrm{W}_{11} \mathrm{x} \\
& \mathrm{E}_{41} \times \mathrm{R}_{41}
\end{aligned}
$$

Atau;

$$
\begin{aligned}
& \mathrm{W}_{11}\left(\mathrm{E}_{11} \times \mathrm{R}_{11}+\mathrm{E}_{21} \times \mathrm{R}_{21}+\mathrm{E}_{31} \times \mathrm{R}_{31}+\mathrm{E}_{41}\right. \\
& x R_{41} \text { ) }
\end{aligned}
$$

Dimana :

$\mathrm{T}_{1}=$ Tujuan pertama dari maqasid syariah (Tahdzib al-Fardi)

$\mathrm{W}_{11}=$ Bobot rata-rata untuk tujuan pertama (Tahzib al Fardi)

$\mathrm{E}_{11}=$ Bobot rata-rata untuk elemen pertama tujuan 1 (E1.Education Grant)

$\mathrm{E}_{21}=$ Bobot rata-rata untuk elemen kedua tujuan 1 (E2.Research)

$\mathrm{E}_{31}=$ Bobot rata-rata untuk elemen ketiga tujuan 1 (E3.Training)

$\mathrm{E}_{41}=$ Bobot rata-rata untuk elemen ke empat tujuan 1 (E4.Publicity)

$\mathrm{R}_{11}=$ Rasio kinerja untuk elemen pertama tujuan 1

$\mathrm{R}_{21}=$ Rasio kinerja untuk elemen kedua tujuan 1

$\mathrm{R}_{31}=$ Rasio kinerja untuk elemen ketiga tujuan 1

$R_{41}=$ Rasio kinerja untuk elemen ke empat tujuan 1

Sehingga, IK $\left(\mathrm{T}_{1}\right)=\mathrm{IK}_{11}+\mathrm{IK}_{21}+\mathrm{IK}_{31}$ $+\mathrm{IK}_{41}$

Dimana,

$$
\begin{aligned}
& \mathrm{IK}_{11}=\mathrm{W}_{11} \times \mathrm{E}_{11} \times \mathrm{R}_{11} \\
& \mathrm{IK}_{21}=\mathrm{W}_{11} \times \mathrm{E}_{21} \times \mathrm{R}_{21} \\
& \mathrm{IK}_{31}=\mathrm{W}_{11} \times \mathrm{E}_{31} \times \mathrm{R}_{31} \\
& \mathrm{IK}_{41}=\mathrm{W}_{11} \times \mathrm{E}_{41} \times \mathrm{R}_{41}
\end{aligned}
$$

b. Iqamah al-Adl (Menegakkan keadilan) = Tujuan $2\left(\mathrm{~T}_{2}\right)$

Indikator Kinerja (IK) untuk Tujuan 2 sebagai berikut :

$\mathrm{IK}\left(\mathrm{T}_{2}\right)=\mathrm{W}_{22} \times \mathrm{E}_{12} \times \mathrm{R}_{12}+\mathrm{W}_{22} \times \mathrm{E}_{22} \times \mathrm{R}_{32}$ $+\mathrm{W}_{22} \times \mathrm{E}_{32} \times \mathrm{R}_{32}$

atau;

$\mathrm{W}_{22}\left(\mathrm{E}_{12} \times \mathrm{R}_{12}+\mathrm{E}_{22} \times \mathrm{R}_{32}+\mathrm{E}_{32} \times \mathrm{R}_{32}\right)(7)$

Sehingga, IK $\left(\mathrm{T}_{2}\right)=\mathrm{IK}_{12}+\mathrm{IK}_{22}+\mathrm{IK}_{32}$ .....(8)

Dimana,

$\mathrm{IK}_{12}=\mathrm{W}_{22} \times \mathrm{E}_{12} \times \mathrm{R}_{12}$
$\mathrm{IK}_{21}=\mathrm{W}_{22} \times \mathrm{E}_{22} \times \mathrm{R}_{32}$
$\mathrm{IK}_{31}=\mathrm{W}_{22} \times \mathrm{E}_{32} \times \mathrm{R}_{32}$

c. Jalb al-Maslahah (Kesejahteraan $)=$ Tujuan $3\left(\mathrm{~T}_{3}\right)$

Indikator Kinerja (IK) untuk Tujuan 3 sebagai berikut:

$\operatorname{IK}\left(\mathrm{T}_{3}\right)=\mathrm{W}_{33} \times \mathrm{E}_{13} \times \mathrm{R}_{13}+\mathrm{W}_{33} \times \mathrm{E}_{23} \mathrm{x}$ $\mathrm{R}_{23}+\mathrm{W}_{33} \times \mathrm{E}_{33} \times \mathrm{R}_{33}$

atau;

$\mathrm{W} 33\left(\mathrm{E}_{13} \times \mathrm{R}_{13}+\mathrm{E}_{23} \times \mathrm{R}_{23}+\mathrm{E}_{33} \times \mathrm{R}_{33}\right)$

Sehingga, $\mathrm{IK}\left(\mathrm{T}_{2}\right)=\mathrm{IK}_{13}+\mathrm{IK}_{23}+\mathrm{IK}_{33}$

Dimana,

$\mathrm{IK}_{12}=\mathrm{W}_{33} \times \mathrm{E}_{13} \times \mathrm{R}_{13}$

$\mathrm{IK}_{21}=\mathrm{W}_{33} \times \mathrm{E}_{23} \times \mathrm{R}_{23}$

$\mathrm{IK}_{31}=\mathrm{W}_{33} \times \mathrm{E}_{33} \times \mathrm{R}_{33}$

3. Menentukan Maqasid Syariah Index (MSI) setiap bank syariah Maqasid Sharia Index (MSI) untuk setiap bank syariah merupakan total semua kinerja indikator dari 3 tujuan maqasid syariah. Sehingga SMI setiap bank syariah dapat dirumuskan sebagai berikut:

$\operatorname{IMS}=\operatorname{IK}\left(\mathrm{T}_{1}\right)+\operatorname{IK}\left(\mathrm{T}_{2}\right)+\operatorname{IK}\left(\mathrm{T}_{3}\right)$

Dengan kata lain SMI untuk setiap bank syariah adalah jumlah total indikator kinerja maqasid syariah tujuan 1, tujuan 2, dan tujuan 3 .

Setelah mengitung nilai Maqasid Syariah Index (MSI) dalam penelitian ini akan dilakukan Uji Independent Sample T Test. Pengujian ini dilakukan dengan menggunakan software SPSS 16. 
Amalia Tery Luana Devi, Fitriyah

HASIL PENELITIAN DAN PEMBAHASAN

Rasio Kinerja Maqashid Syariah Indonesia dan Malaysia

Tabel 3 Rasio Kinerja Perbankan Syariah Indonesia dan Malaysia Tahun 2011-2015

\begin{tabular}{|c|c|c|c|c|c|c|c|c|c|c|}
\hline \multicolumn{11}{|c|}{ Bank Umum Syariah (BUS) Indonesia } \\
\hline Rasio & $\mathbf{R}_{11}$ & $\mathbf{R}_{21}$ & $\mathbf{R}_{31}$ & $\mathbf{R}_{41}$ & $\mathbf{R}_{12}$ & $\mathbf{R}_{22}$ & $R_{32}$ & $\mathbf{R}_{13}$ & $\mathbf{R}_{23}$ & $\mathbf{R}_{33}$ \\
\hline BMI & $0.16 \%$ & $0.62 \%$ & $1.05 \%$ & $4.22 \%$ & $0.00 \%$ & $49.12 \%$ & $99.97 \%$ & $0.16 \%$ & $0.01 \%$ & $91.40 \%$ \\
\hline BVS & $0.00 \%$ & $0.00 \%$ & $0.47 \%$ & $1.19 \%$ & $0.00 \%$ & $36.73 \%$ & $99.55 \%$ & $0.20 \%$ & $0.01 \%$ & $76.42 \%$ \\
\hline BRIS & $0.01 \%$ & $0.00 \%$ & $1.37 \%$ & $2.78 \%$ & $0.00 \%$ & $24.96 \%$ & $99.99 \%$ & $0.51 \%$ & $0.01 \%$ & $96.03 \%$ \\
\hline BJBS & $0.56 \%$ & $0.00 \%$ & $1.83 \%$ & $4.65 \%$ & $0.00 \%$ & $2.51 \%$ & $100 \%$ & $1.68 \%$ & $0.00 \%$ & $99.93 \%$ \\
\hline BNIS & $0.40 \%$ & $0.00 \%$ & $2.69 \%$ & $5.82 \%$ & $0.00 \%$ & $11.68 \%$ & $99.99 \%$ & $0.87 \%$ & $0.05 \%$ & $91.69 \%$ \\
\hline BSM & $0.25 \%$ & $0.10 \%$ & $8.16 \%$ & $2.70 \%$ & $0.00 \%$ & $24.40 \%$ & $99.99 \%$ & $0.80 \%$ & $0.03 \%$ & $94.13 \%$ \\
\hline BMS & $0.03 \%$ & $0.00 \%$ & $0.43 \%$ & $0.68 \%$ & $0.00 \%$ & $1.00 \%$ & $99.83 \%$ & $1.09 \%$ & $0.04 \%$ & $91.23 \%$ \\
\hline BPS & $0.04 \%$ & $0.00 \%$ & $1.03 \%$ & $0.82 \%$ & $0.00 \%$ & $64.95 \%$ & $99.97 \%$ & $1.01 \%$ & $0.01 \%$ & $92.35 \%$ \\
\hline BSB & $0.12 \%$ & $0.00 \%$ & $1.13 \%$ & $1.53 \%$ & $0.00 \%$ & $35.83 \%$ & $99.98 \%$ & $0.42 \%$ & $0.00 \%$ & $95.31 \%$ \\
\hline BCAS & $0.00 \%$ & $0.00 \%$ & $1.52 \%$ & $1.23 \%$ & $0.00 \%$ & $43.17 \%$ & $99.75 \%$ & $0.53 \%$ & $0.00 \%$ & $89.36 \%$ \\
\hline MSI & $0.00 \%$ & $0.00 \%$ & $1.69 \%$ & $1.93 \%$ & $0.00 \%$ & $5.54 \%$ & $99.80 \%$ & $-1.69 \%$ & $0.00 \%$ & $83.41 \%$ \\
\hline \multicolumn{11}{|c|}{ Bank Umum Syariah (BUS) Malaysia } \\
\hline Rasio & $\mathbf{R}_{11}$ & $\mathbf{R}_{21}$ & $\mathbf{R}_{31}$ & $R_{41}$ & $R_{12}$ & $\mathbf{R}_{22}$ & $\mathbf{R}_{32}$ & $\mathbf{R}_{13}$ & $\mathbf{R}_{23}$ & $\mathbf{R}_{33}$ \\
\hline AFFIN & $0.98 \%$ & $0.00 \%$ & $0.00 \%$ & $0.84 \%$ & $0.00 \%$ & $13.31 \%$ & $100 \%$ & $0.55 \%$ & $0.05 \%$ & $79.81 \%$ \\
\hline ABCIB & $0.00 \%$ & $0.00 \%$ & $0.00 \%$ & $0.00 \%$ & $0.00 \%$ & $6.51 \%$ & $100 \%$ & $2.69 \%$ & $0.05 \%$ & $81.76 \%$ \\
\hline AIBB & $0.00 \%$ & $0.00 \%$ & $0.00 \%$ & $2.46 \%$ & $0.00 \%$ & $0.00 \%$ & $100 \%$ & $0.85 \%$ & $0.00 \%$ & $72.66 \%$ \\
\hline AIB & $0.00 \%$ & $0.00 \%$ & $0.00 \%$ & $1.42 \%$ & $0.81 \%$ & $0.06 \%$ & $100 \%$ & $0.64 \%$ & $0.00 \%$ & $85.63 \%$ \\
\hline AFBB & $0.00 \%$ & $0.00 \%$ & $0.00 \%$ & $0.45 \%$ & $0.10 \%$ & $0.00 \%$ & $100 \%$ & $0.21 \%$ & $0.00 \%$ & $69.36 \%$ \\
\hline BIMB & $0.12 \%$ & $0.00 \%$ & $0.00 \%$ & $1.30 \%$ & $0.00 \%$ & $0.01 \%$ & $100 \%$ & $1.11 \%$ & $0.02 \%$ & $64.43 \%$ \\
\hline BMMB & $0.00 \%$ & $0.00 \%$ & $0.00 \%$ & $2.97 \%$ & $0.00 \%$ & $0.41 \%$ & $100 \%$ & $0.58 \%$ & $0.02 \%$ & $64.72 \%$ \\
\hline CIMB & $0.00 \%$ & $0.00 \%$ & $0.00 \%$ & $1.69 \%$ & $0.00 \%$ & $0.00 \%$ & $100 \%$ & $0.77 \%$ & $0.09 \%$ & $84.00 \%$ \\
\hline HSBC & $0.00 \%$ & $0.00 \%$ & $0.00 \%$ & $8.55 \%$ & $1.05 \%$ & $38.72 \%$ & $100 \%$ & $0.87 \%$ & $0.00 \%$ & $84.50 \%$ \\
\hline HLIBB & $0.00 \%$ & $0.00 \%$ & $0.24 \%$ & $1.43 \%$ & $0.46 \%$ & $0.00 \%$ & $100 \%$ & $0.42 \%$ & $0.00 \%$ & $71.91 \%$ \\
\hline KFHB & $0.00 \%$ & $0.00 \%$ & $0.00 \%$ & $2.99 \%$ & $0.00 \%$ & $6.01 \%$ & $100 \%$ & $-0.69 \%$ & $0.00 \%$ & $83.68 \%$ \\
\hline MIB & $0.00 \%$ & $0.00 \%$ & $0.00 \%$ & $1.30 \%$ & $2.65 \%$ & $5.09 \%$ & $100 \%$ & $0.79 \%$ & $0.01 \%$ & $89.55 \%$ \\
\hline OCBC & $0.00 \%$ & $0.00 \%$ & $0.00 \%$ & $1.67 \%$ & $0.00 \%$ & $4.31 \%$ & $100 \%$ & $0.71 \%$ & $0.00 \%$ & $71.26 \%$ \\
\hline RHB & $0.00 \%$ & $0.00 \%$ & $0.00 \%$ & $3.22 \%$ & $0.29 \%$ & $18.81 \%$ & $100 \%$ & $0.56 \%$ & $0.00 \%$ & $81.37 \%$ \\
\hline SCSB & $0.00 \%$ & $0.00 \%$ & $0.00 \%$ & $0.36 \%$ & $0.00 \%$ & $20.23 \%$ & $100 \%$ & $0.53 \%$ & $0.00 \%$ & $90.72 \%$ \\
\hline
\end{tabular}

Rasio Kinerja Maqashid Syariah Tujuan Pertama (Tahdzib al-Fard) Indonesia dan Malaysia

Education Grant/Total Income (R11)

Di Indonesia yang menyalurkan hibah pendidikan terbesar adalah Bank Jabar Banten Syariah (BJBS) yang memiliki prosentase $0.56 \%$. dari total beban yang dikeluarkannya. Sementara itu di Malaysia adalah Affin Islamic Bank Berhad (AFFIN) rasio sebesar $0.98 \%$. Hal tersebut menunjukkan bahwa bank umum syariah di Indonesia memiliki kontribusi yang lebih besar dibandingkan bank umum syariah yang ada di Malaysia dalam hal hibah pendidikan. Dengan adanya biaya pendidikan yang disalurkan kepada masyarakat oleh bank umum syariah diharapkan dapat berperan dalam mengembangkan pengeta- huan masyarakat karena Pendidikan bisa dikatakan sebagai salah satu kunci pembentukan sumber daya manusia yang berkualitas.

\section{Research Expense/Total Expense (R21)}

Di Indonesia, terdapat dua bank umum syariah yang mengeluarkan biaya penelitian atau pengembangan (research and development) untuk keberlangsungan kegiatan operasionalnya, yaitu Bank Muamalat Indonesia (BMI) dengan nilai rasio $0.62 \%$. Berdasarkan analisis data, bank umum syariah di Malaysia belum ada yang melaporkan atau menjelaskan secara rinci mengenai biaya penelitian (research expense). Padahal perkembangan asset perbankan syariah di Malaysia dapat dikatakan lebih cepat diban- 
dingkan perbankan syariah yang ada di Indonesia. Oleh karena itu Malaysia perlu memperhatikan kembali mengenai alokasi biaya penelitian mengingat persaingan industri pada saat ini sudah semakin ketat, dan terbukti bahwa prinsip-prinsip yang digunakan oleh bank syariah sudah mulai diterima oleh Negara non muslim.

\section{Training Expense/Total Expense (R31)}

Adanya pengalokasian dana oleh bank umum syariah untuk biaya pendidikan dan pelatihan karyawan merupakan salah satu bentuk implementasi dari konsep hifzul aql (penjagaan terhadap akal) dan hifzhun nafs (penjagaan terhadap jiwa).

Dalam rangkan meningkatkan kualitas karyawan, secara keseluruhan bank umum syariah di Indonesia telah mengalokasikan biaya untuk pelatihan karyawan. Bank Syariah Mandiri (BSM) dalam hal ini memperoleh nilai rasio yang lebih unggul dibandingkan bank syariah lainnya dengan nilai rasio sebesar $8.16 \%$. sementara itu, dari 15 bank umum syariah di Malaysia hanya Hong Leong Islamic Bank Berhad (HLIBB) yang menjelaskan secara rinci mengenai alokasi biaya pendidikan dan pelatihan hal tersebut diperkuat dengan nilai rasio yang diperolehnya sebesar $1.43 \%$.

\section{Publicity Expense/Total Expense (R41)}

Bank Syariah memiliki peran untuk memberikan pengetahuan mengenai perbankan syariah kepada masyarakat. Salah satunya dengan melakukan sosialisasi dan publikasi mengenai bentuk informasi produk bank syariah dan operasionalnya.

Di Indonesia hampir semua bank umum syariah mengalokasikan dananya untuk promosi/publikasi. Salah satu bank umum syariah yang memperoleh nilai rasio tertinggi dalam hal ini adalah BNI Syariah (BNIS) dengan nilai 5.82\%. sementara itu, nilai rasio tertinggi untuk bank umu syariah di Malaysia diperoleh HSBC Amanah Malaysia Berhad dengan nilai $8.55 \%$

\section{Rasio Kinerja Maqashid Syariah Tujuan Kedua (Iqamah al-Adl) Indonesia dan Malaysia}

\section{Profit Equalization Reserves (PER) / Net Or In- vestment Income (R12)}

Bank syariah dituntut untuk melakukan transaksi yang adil salah satunya dengan memberikan pe- ngembalian yang adil kepada nasabahnya (fair return).

Berdasarkan analisis, hampir semua bank umum syariah di Indonesia belum mengungkapan berapa tingkat PER (Profit Equalisation Ratio) dalam laporan tahunannya. Berbeda halnya dengan Indonesia, Profit Equalization Reserve (PER) diperbolehkan di digunakan oleh BankBank Syariah di Malaysia sekitar 12 tahun yang lalu. Berdasarkan hasil perhitungan, bank umum syariah yang memperoleh nilai tertinggi dalam rasio ini adalah Affin Islamic Bank Berhad (AFFIN) dengan nilai 32.43\%. Akan tetapi, tidak semua bank umum syariah di Malaysia yang menerapkan adanya PER (Profit Equalization Reserve) dalam laporan tahunannya.

\section{Mudharabah And Musyarakah Modes/Total In- vestment Mode (R22)}

Fungsi distribusi dalam hal ini menggambarkan seberapa besar pembiayaan dengan akad bagi hasil mudharabah dan musyarakah dalam terhadap seluruh akad pembiayaan yang diberikan bank syariah.

Berdasarkan hasil perhitungan, bank umum syariah di Indonesia yang mempereoleh nilai rasio tertinggi adalah Bank Panin Syariah (BPS), dengan nilai $64.95 \%$. Sedangkan HSBC Amanah Malaysia Berhad (HSBC) menjadi leader bagi perbankan syariah di Malaysia, dengan nilai rasio $38.72 \%$. Namun, banyak juga bank umum syariah yang tidak menggunakan akad mudharabah dan musyarakah dalam pembiayaannya. Hal tersebut dikarenakan akad mudharabah dan musyarakah lebih diterapkan pada pos-pos penempatan dana (investasi) seperti deposito, sedangkan akat dalam transaksi pembiayaan lebih didominasi oleh akad murabahah dan ijarah muntaiha bi tamlik rata-rata diterapkan oleh setiap bank umum syariah di Malaysia.

\section{Interest Free Income/Total Income (R32)}

Salah satu prinsip perbankan syariah adanya melarang adanya riba (suku bunga), hal tersebut dikarenakan riba dapat memberikan dampak buruk terhadap perekonomian dan menyebabkan ketidak adilan dalam transaksi ekonomi. Dalam hal ini hampir semua bank umum syariah di Indonesia memperoleh nilai $100 \%$ untuk kategori produk-produk dalam kegiatan opera- 
sionalnya yang terbebas dari bunga. Sementara itu pada bank umum syariah di Malaysia, hampir semuanya memperoleh nilai rasio $100 \%$, artinya produk-produk yang ditawarkan adalah produk bebas bunga.

\section{Rasio Kinerja Maqashid Syariah Tujuan Ketiga (Jalb al-Maslahah) Indonesia dan Malaysia}

\section{Net Income/Total Asset (R13)}

Rasio ini bertujuan untuk mengetahui kemampuan perusahaan dalam menghasilkan laba selama periode tertentu dan juga memberikan gambaran tentang tingkat efektifitas manajemen dalam melaksanakan kegiatan operasinya. Semakin besar keuntungan yang diperoleh bank umum syariah, maka akan berdampak pada peningkatan kesejahteraan, tidak hanya pada pemilik dn pegaiwainya saja akan tetapi dapat berdampak pada semua stakeholder perbankan syariah.

Salah satu bank umum syariah di Indonesia yang memperoleh nilai rasio tertinggi untuk rasio laba bersih adalah Bank Jabar Banten Syariah (BJBS) dengan nilai perolehan $1.68 \%$. Untuk bank umum syariah di Malaysia, rasio tertinggi diperoleh AlRajhi Banking and Investment Corporate Berhad (ABICB) dengan nilai rasio 2.69\%. nilai tersebut lebih tinggi jika dibandingkan dengan bank umum syariah di Indonesia, artinya Al-Rajhi Banking and Investment Corporate Berhad (ABICB) dengan nilai rasio yang semakin tinggi menunjukkan bahwa suatu perusahaan semakin efisien dalam memanfaatkan aktifitasnya untuk memperoleh laba, sehingga nilai perusahaan meningkat.

\section{Zakah Paid/Net Asset (R23)}

Perbankan syariah selalu berupaya untuk peduli terhadap sesama dengan ikut mengentaskan masalah-masalah sosial yang dihadapi masyarakat. Dalam ajaran Islam, prinsip kepedulian sosial ini diwujudkan melalui konsep zakat, infak, dan sedekah. Umat diharuskan harus bertanggung jawab secara material terhadap kemiskinan yang ada di lingkungannya. Lebih jauh konsep zakat ditujukan untuk memelihara agama, akal, jiwa, keturunan, dan harta.

Di Indonesia, BNI Syariah memperoleh nilai rasio tertinggi dalam pendistribusian zakatnya, yaitu sebesar $0.05 \%$. Sementara itu, dari 15 bank umum syariah yang menjadi sampel, terdapat 5 bank umum syariah yang melaporkan pendistribusian zakatnya. 5 bank tersebut diantaranya : Affin Islamic Bank Berhad (AFFIN), Al-Rajhi Banking \& Investment Corporate Berhad (ABICB), Bank Islamic Malaysia Berhad (BIMB), Bank Muamalat Malaysia Berhad (BMMB), dan CIMB Islamic Bank Berhad. Dari hasil perhitungan, bank yang memperoleh nilai rasio tertinggi adalah CIMB Islamic Bank Berhad dengan nilai $0.09 \%$.

\section{Investment In Real Econoic Sectors/Total Invest- ment (R33)}

Keberadaan bank umum syariah diharapkan dapat memberikan kontribusinya dalam pertumbuhan sektor riil, semakin besar nilai rasio atas investasi sektor riil semakin akan memberikan kemaslahatan kepada seluruh lapisan masyarakat.

Bank umum syariah di Indonesia yang memperoleh nilai rasio tertinggi pada investasi sektor riil adalah Bank jabar Banten Syariah (BJBS) dengan nilai $99.93 \%$. Sementara itu, di Malaysia untuk perolehan nilai rasio tertinggi yaitu Standard Chartered Saadiq Berhad (SCSB) dengan prosentase rasio sebesar $90.72 \%$. Jika dibandingkan dengan bank umum syariah yang ada di Indonesia, dalam hal rasio investasi ke sektor riil bank umum syariah di Malaysia masih dibawah bank umum syariah di Indonesia.

Perbandingan Kinerja Perbankan Syariah Indonesia dan Malaysia Berdasarkan Nilai Maqashid Syariah Index (MSI)

Tabel 4 Nilai Maqasid Syariah Index (MSI) dan Peringkat Bank Umum Syariah Indonesia

\begin{tabular}{lccc}
\hline Bank & MSI & Rangking & $\begin{array}{c}\text { Rangking } \\
\text { Gabungan }\end{array}$ \\
\hline BPS & 0.34243 & 1 & 1 \\
BMI & 0.32316 & 2 & 2 \\
BCAS & 0.31048 & 3 & 3 \\
BSB & 0.30747 & 4 & 4 \\
BSM & 0.29808 & 5 & 5 \\
BRIS & 0.29507 & 6 & 6 \\
BVS & 0.28668 & 7 & 7 \\
BNIS & 0.27677 & 8 & 8 \\
BJBS & 0.27296 & 9 & 9 \\
BMS & 0.25664 & 10 & 11 \\
MSI & 0.25329 & 11 & 12 \\
\hline
\end{tabular}

Sumber : data diolah, 2017 
Tabel 5 Nilai Maqasid Syariah Index (MSI) dan Peringkat Bank Umum Syariah Malaysia

\begin{tabular}{lccc}
\hline Bank & MSI & Rangking & Rangking Gabungan \\
\hline HSBC & 0.26932 & 1 & 10 \\
SCSB & 0.24598 & 2 & 13 \\
RHB & 0.23656 & 3 & 14 \\
MIB & 0.23027 & 4 & 15 \\
AFFIN & 0.22686 & 5 & 16 \\
KFHB & 0.22158 & 6 & 17 \\
ABICB & 0.22136 & 7 & 18 \\
AIB & 0.21754 & 8 & 19 \\
CIMB & 0.21512 & 9 & 20 \\
OCBC & 0.20660 & 10 & 21 \\
AIBB & 0.20348 & 11 & 22 \\
HLIBB & 0.20230 & 12 & 23 \\
AFBB & 0.19806 & 13 & 24 \\
BMMB & 0.19557 & 14 & 25 \\
BIMB & 0.19421 & 15 & 26 \\
\hline
\end{tabular}

Sumber : data diolah, 2017

Berdasarkan tabel diatas dapat dijelaskan bahwa bank umum syariah di Indonesia yang mememiliki pencapaian kinerja terbaik berdasarkan aspek maqashid syariah selama tahun pengamatan 20112015 adalah Bank Panin Syariah (BPS) dengan MSI sebesar 0.34243. Kemudian untuk bank umum syariah Malaysia yang berhasil mencapai kinerja tertinggi berdasarkan aspek maqashid syariah adalah HSBC Amanah Malaysia Berhad (HSBC) dengan nilai SMI sebesar 0.26932 .

Untuk peringkat tertinggi atas kinerja bank umum syariah Indonesia dan Malaysia diperoleh Bank Panin Syariah (BPS). Hal ini menunjukkan bahwa pencapaian kinerja perbankan syariah Indonesia lebih baik dari segi maqashid syariah dibandingkan dengan perbankan syariah di Malaysia. Nilai MSI tersebut didukung oleh pencapaian indicator kinerja tujuan kedua yang lebih tinggi, Bank Panin Syariah memberikan kontribusi yang besar dalam tujuan penegakan keadilan, aspek keadilan mensyaratkan bahwa bank harus bersikap jujur dan adil dalam pengoperasiannya serta harus mengembangkan investasi yang dapat meningkatkan kesejahteraan masyarakat.

Hal tersebut didukung oleh hasil output SPSS Uji Independent Sample T Test yang menunjukkan nilai t pada equal variance assumed adalah 7.861 dengan probabilitas signifikansi 0.000 (2-tailed). Karena 0.000 $<0.05$ maka dapat disimpulkan bahwa rata-rata nilai Maqasid Syariah Index (MSI) berbeda secara signifikan antara BUS Indonesia dan Malaysia.

\section{KESIMPULAN}

Berdasarkan hasil analisis data dan pembahasan dapat ditarik kesimpulan sebagai berikut: kinerja perbankan syariah di Indonesia berdasarkan konsep maqashid syariah menunjukkan bahwa perbankan syariah Indonesia dalam melaksanakan kegiatan operasionalnya yang sesuai dengan tujuan syariah lebih dominan pada tujuan Iqamah Al-Adl. Artinya, perbankan syariah Indonesia lebih maksimal dalam hal menerapkan prinsip-prinsip syariah syariah terutama prinsip bagi hasil dalam operasionalnya. Bank umum syariah di Indonesia yang memperoleh pencapaian terbaik sesuai dengan nilai Maqashid Syariah Index (MSI) adalah Bank Panin Syariah (BPS).

Kinerja perbankan syariah di Malaysia berdasarkan konsep maqashid syariah menunjukkan bahwa kurangnya penerapan prinsip syariah pada perbankan syariah di Malaysia terutama dalam hal Tahdzib AlFard sehingga, keberadaan perbankan syariah di Malaysia masih belum bisa dirasakan secara maksimal dalam upaya memberikan manfaat dalam hal pendidikan bagi pegawai maupun masyarakat sekitarnya. Namun demikian, Bank umum syariah di Malaysia yang memperoleh pencapaian terbaik sesuai dengan nilai Maqashid Syariah Index (MSI) adalah HSBC Amanah Malaysia Berhad (HSBC).

Industri perbankan syariah Indonesia memiliki nilai lebih dalam rangka pencapaian tujuan syariah (maqashid syariah). Oleh karenanya terdapat perbedaan kinerja perbankan syariah di Indonesia dan Malaysia berdasarkan nilai Maqashid Syariah Index (MSI).

\section{SARAN}

Berdasarkan kesimpulan diatas, saran yang dapat diberikan antara lain : Bagi dunia perbankan, untuk dapat mengevaluasi kinerjanya dengan lebih memberikan perhatian terhadap pengungkapan aspek-aspek syariah dan terus mempertahankan sistem operasional yang sudah sesuai dengan prinsip syariah. Bagi peneliti selanjutnya, diharapkan untuk menggunakan alat ukur lain dalam mengukur kinerja perbankan yang didasarkan pada konsep maqashid syariah. Atau dapat membandingkan antar alat ukur lainnya yang juga didasarkan pada konsep maqashid syariah

\section{DAFTAR PUSTAKA}

Afrinaldi. (2013). Analisa Kinerja Perbankan Syariah Indonesia Ditinjau dari Maqasid Syariah: Pendekatan 
Syariah Maqasid Index (SMI) dan Profitabilitas Bank Syariah. Paper Forum Riset Ekonomi dan Keuangan Syariah di UIN Syarif Hidayatullah. Indonesia

Bank Indonesia. 2012. Kajian Model Bisnis Perbankan Syariah.

Ernest, \& Young. (2016). World Islamic Banking Competitivness Report.

Fauzia, Ika Yunia., Riyadi, Abdul Kadir. (2014). Prinsip Dasar Ekonomi Islam Perspektif Maqashid alSyariah. Jakarta: Kencana.

Ghozali, Imam. (2005). "Aplikasi Analisis Multivariate Dengan Program SPSS”. Semarang: Badan Penerbit Universitas Diponegoro.

Hameed, Shahul, et. al., (2004). "Alternative Disclosure dan Performance for Islamic Bank's. Proceeding of The Second Conference on Administrative Science: Meeting The Challenges of The Globalization Age. Dahran, Saud Arabia.

IFSB (Islamic Financial Services Board). (2015). Islamic Financial Service Industry Stability Report.

Imansari, Anisa Dyah. (2015). Analisis Perbandingan Kinerja Perbankan Syariah berdasarkan Konsep AlMaqashid Al-Syariah di Indonesia dan Malaysia. Skripsi Fakultas Ekonomika dan Bisnis. Universitas Diponegoro.

Kuppusamy, Mudiarasan, et al, (2010). Measurement of Islamic Banks Performance Using a Shari'ah Confor- mity and Profitablity Model. International Association for Islamic Economics Review of Islamic Economics, Vol. 13, No. 2

Mohammed, Mustafa Omar and Shahwan, Syahidawati. (2013). The Objective of Islamic Economic and Islamic Banking in Light of Maqasid Al-Shariah: A Critical Review, Middle-East Journal of Scientific Research 13 (Research in Contemporary Islamic Finance and Wealth Management): 75-84.

Mohammed, Mustafa Omar., Razak, Djulzastri Abdul. \& Taib, F. M. (2008). The Performance Measures of Islamic Banking Based on the Maqasid Framework. Paper of IIUM International Accounting Conference (INTAC IV) held at Putra Jaya Marroitt, 1-17.

Roadmap Perbankan Syariah Indonesia. Otoritas Jasa Keuangan (OJK). 2016

Roza, Ida. (2015). Analisis Perbandingan Kinerja Perbankan Syariah dengan Metode Indeks Maqasid Syariah dan CAMEL. Skripsi UIN Sunan Kalijaga. Yogyakarta Sekaran, Umar. (2006). Research Methods for Business. Jakarta: Salemba Empat.

h t t p : / / w w w . b n m . g o v . m y / ?ch=li\&cat=islamic\&type $=I B \& l a n g=e n($ diakses pada tanggal 04 Januari 2017, pukul 19.24 WIB)

http://tafsirq.com/9-at-taubah/ayat-105\#tafsir-quraishshihab (diakses pada tanggal 19 April 2017, pukul 23.44 WIB) 